\title{
Endophytic Bacillus spp. from Wild Solanaceae and Their Antifungal Potential against Fusarium oxysporum f. sp. lycopersici Elucidated Using Whole Cells, Filtrate Cultures and Organic Extracts
}

\author{
Rania Aydi Ben Abdallah ${ }^{1,2 *}$, Hayfa Jabnoun-Khiareddine ${ }^{2}$, Sonia Mokni-Tlili ${ }^{3}$, Ahlem Nefzi ${ }^{2,4}$, Sined Medimagh-Saidana ${ }^{5}$ and Mejda Daami- \\ Remadi $^{2}$ \\ ${ }^{1}$ National Agronomic Institute of Tunisia, 1082 Tunis Mahrajène, University of Carthage, Tunisia \\ ${ }^{2}$ UR13AGR09- Integrated Horticultural Production in the Tunisian Centre-East, Regional Center of Research on Horticulture and Organic Agriculture, University of Sousse, \\ 4042, Chott-Mariem, Tunisia \\ ${ }^{3}$ Department of Biology, Science College in Abha of Girls, King Khalid University; Research Center and Water Technology, Borj Cedria, Tunisia \\ ${ }^{4}$ University of Carthage, 1054, Tunis, Tunisia. \\ ${ }^{5}$ LR11SE39-Laboratory of Heterocyclic Chemistry, Natural Products and Reactivity, University of Monastir, Tunisia
}

\begin{abstract}
Six isolates of culturable bacteria, isolated from stems of wild Solanaceae species (Datura metel, Solanum nigrum, S. elaeagnifolium, and Nicotiana glauca), were assessed for their antifungal activity against $F$. oxysporum $\mathrm{f}$. $\mathrm{sp}$. Iycopersici (FOL), the causal agent of the tomato Fusarium wilt. Blast analysis of $16 \mathrm{~S}$ rDNA sequencing genes homology showed that the isolates belonged to the genus Bacillus (Bacillus cereus str. S42, $B$. tequilensis str. SV39, B. subtilis str. SV41, B. methylotrophicus str. SV44, B. amyloliquefaciens subsp. plantarum str. SV65, and B. mojavensis str. SV104). The mycelium growth of FOL was significantly reduced by 36 to $46 \%$ by diffusible metabolites and by 18 to $21 \%$ by volatile compounds. Cell-free cultures were found to be mostly active when issued from 4 daysold cultures where FOL growth inhibition significantly varied from 31.1 to $59.5 \%$. Active metabolites present in the cell-free cultures were extracted with $n$-butanol and chloroform. Both organic extracts exhibited antifungal potential towards FOL higher than that induced by the two commercial products i.e. Bavistin ${ }^{\circledR}(50 \%$, chemical fungicide) and Bactospeine ${ }^{\circledR}(16000 \mathrm{Ul} / \mathrm{mg}$, biopesticide). This study clearly indicates that endophytic Bacillus spp. from wild Solanaceae species can be used as natural sources of bioactive metabolites towards FOL. Wild Solanaceae are frequent in Tunisia and were not explored as potent sources of candidate antagonistic bacteria. In view of the endogenous progress of the pathogen via the vascular tissues, the use of endophytic bacteria can suppress tomato Fusarium wilt disease.
\end{abstract}

Keywords: Antifungal activity; Bacillus spp.; Cell-free cultures; Fusarium oxysporum f. sp. lycopersici; Metabolites; Organic extracts

\section{Introduction}

Fusarium oxysporum f. sp. lycopersici (Sacc.) W.C. Snyder \& H.N. Hans is one of the most important pathogens infecting tomato worldwide $[1,2]$. Fusarium oxysporum f. sp. lycopersici (FOL) is a widespread pathogen and wilt severity depends on regional cultural practices [3]. This pathogen is responsible for important crop losses both in open field and protected crops $[1,4,5]$.

Use of resistant cultivars, crop rotation and solarization have been widely used for the control of soilborne fungal diseases but they did not give satisfactory results [6]. Moreover, due to the development of resistance mutations and due to the emergence of new physiological races, many of synthetic chemicals fungicides and resistant cultivars are gradually becoming ineffective in controlling the disease [7].

The control of Fusarium wilt of tomato is so difficult due to the endogenous progress of the pathogen via the vascular tissues [8] and to the limited range of effective fungicides [9]. Besides, the long survival of chlamydospores in the soil, for extended periods without a host, limited the suppressive effects of crop rotation $[1,8]$. Added to these constraints, the resistance of tomato cultivars to races 1 and 2 of FOL, which has long been adopted as an effective and safe alternative to human and the environment, was overcome by the emergence of the race 3 of the pathogen in several countries [5,10]. Research studies have been more focused on sources of genetic resistance to this emergent race and on alternative practices for achieving an effective control of this pathogen [10].
Therefore, there is an increasing interest in the development of control alternatives.

Biological control was considered as an environmentally safe alternative. Given the endogenous progress of the pathogen within plant tissues, the use of endophytic microorganisms could better limit the disease [11-13].

Endophytic bacteria, used as whole cells [14,15], cell-free culture filtrates and/or organic extracts [16,17] gave satisfactory results in controlling some plant pathogenic fungi. These biocontrol agents (BCAs) have been isolated from a variety of plants because they ubiquitously inhabit mostly wild species such as Prosopis strombulifera [18], Huperzia serrata [19], Suaeda maritima, Carex scabrifolia, and Elymus mollis [20]. Recently, a wild Solanaceae, Nicotiana glauca, was

*Corresponding author: Rania Aydi Ben Abdallah, National Agronomic Institute of Tunisia, 1082 Tunis Mahrajène, University of Carthage, Tunisia, Tel: +21671749100; E-mail: raniaaydi@yahoo.fr

Received December 12, 2015; Accepted December 21, 2015; Published December 24, 2015

Citation: Aydi Ben Abdallah R, Jabnoun-Khiareddine H, Mokni-Tlili S, Nefzi A, Medimagh-Saidana S, et al. (2015) Endophytic Bacillus spp. from Wild Solanaceae and Their Antifungal Potential against Fusarium oxysporum f. sp. Iycopersici Elucidated Using Whole Cells, Filtrate Cultures and Organic Extracts. J Plant Pathol Microbiol 6: 324. doi:10.4172/2157-7471.1000324

Copyright: ( 2015 Aydi Ben Abdallah R, et al. This is an open-access article distributed under the terms of the Creative Commons Attribution License, which permits unrestricted use, distribution, and reproduction in any medium, provided the original author and source are credited. 
Citation: Aydi Ben Abdallah R, Jabnoun-Khiareddine H, Mokni-Tlili S, Nefzi A, Medimagh-Saidana S, et al. (2015) Endophytic Bacillus spp. from Wild Solanaceae and Their Antifungal Potential against Fusarium oxysporum f. sp. Iycopersici Elucidated Using Whole Cells, Filtrate Cultures and Organic Extracts. J Plant Pathol Microbiol 6: 324. doi:10.4172/2157-7471.1000324

used as natural source of beneficial leaf-associated bacteria, especially Bacillus spp. [21].

Previous studies used endophytic bacteria as BCAs against plant pathogenic fungi such as $F$. oxysporum f. sp. cubense, Colletotrichum gloeosporioides, Alternaria alternata, Botrytis cinerea, B. fabae, Pythium ultimum, Rhizoctonia solani, Verticillium dahliae, Sclerotium rolfsii, Sclerotinia sclerotiorum and Penicillium digitatum [15,22,23].

Therefore, searching for new bioactive metabolites from endophytic bacteria is a new and safe way of controlling plant diseases [16,24]. These metabolites from Bacillus species include lipopeptide antibiotics $[12,25]$, cell-degrading enzymes $[14,26]$ and other substances belonging to esters, ketones, alcohols, aldhehydes and phthalic acids families [27].

In this study, endophytic bacteria isolated from healthy stems of wild Solanaceae plants (N. glauca, D. metel, S. elaeagnifolium and S. nigrum) were identified and tested in vitro for their antifungal activity against FOL. Their cell-free culture filtrates and organic extracts were also evaluated for their suppressive effects towards FOL.

\section{Materials and Methods}

\section{Pathogen isolation and culture}

The isolate of Fusarium oxysporum f. sp. lycopersici (FOL) used in this study was originally isolated from tomato plants exhibiting typical symptoms of Fusarium wilt. Stem sections (3-5 cm in length) showing vascular discoloration were rinsed thoroughly with tap water. After surface-disinfesting in sodium hypochlorite solution (5\%) for $2 \mathrm{~min}$, the stem pieces $(1 \mathrm{~cm}$ in length) were rinsed three times with steriledistilled water (SDW) and dried on sterile filter paper. They were plated onto Potato Dextrose Agar (PDA) medium amended with streptomycin sulfate $(300 \mathrm{mg} / \mathrm{L})(\mathrm{w} / \mathrm{v})$. Fungal cultures were incubated for one week at $25^{\circ} \mathrm{C}$. The fungal isolate was cleaned up by subculturing successively and selected by single-spore isolation. The isolate of FOL selected was re-isolated from artificially inoculated tomato cv. Rio Grande plants fulfilling Koch's postulates and incubated at $25^{\circ} \mathrm{C}$ for 7 days before use.

\section{Plant sampling and endophytic bacteria isolation and culture}

Healthy wild Solanaceae species (N. glauca, D. metel, S. nigrum and $S$. elaeagnifolium) growing spontaneously nearby tomato fields with a history of severe soilborne diseases, were used for isolation of endophytic bacteria. Stems were sampled, at the fruiting stage, on April and November 2013 from different ecological sites of the Tunisian Centre-East (Chott-Mariem, Bekalta, M'saken). Stems were washed with tap water and processed for endophytic bacteria isolation as follows.

Five stem Samples (5 $\mathrm{cm}$ in length) were individually disinfected by soaking into $70 \%$ ethanol for $1 \mathrm{~min}$, immersion in $1 \%$ sodium hypochlorite solution for $10 \mathrm{~min}$ then in $70 \%$ ethanol for $30 \mathrm{~s}$. They were rinsed three times in SDW and air-dried on sterile filter papers. After check for the efficiency of the surface sterilization procedure according to McInroy and Kloepper [28], two methods of endophytic bacteria isolation were used. The first one consisted of transferring aseptically twenty pieces ( $1 \mathrm{~cm}$ in length) of sterile stems onto Nutrient Agar (NA) medium. This method was used to isolate endophytic bacteria from surface-sterilized stems. In the second method, three stem pieces were pierced with a sterile-nipper and the liquid exuding from the internal tissues was streaked on NA. This method was used to isolate endophytic bacteria from internal tissues of stems (Table 1). Before be used in the different bioassays, stored cultures in NA supplemented with $40 \%$ glycerol at $-20^{\circ} \mathrm{C}$ were subcultured on NA and incubated at $25^{\circ} \mathrm{C}$ for $48 \mathrm{~h}$.

\section{Characterization and hypersensivity test of endophytic bacterial isolates}

Colonies of bacterial isolates were observed macroscopically and characterized based on their size, shape, margin, elevation, texture, opacity, consistency and pigmentation on NA. Morphology, mobility and Gram's staining of culturable isolates were performed using light microscopy [29]. Isolates were also characterized using conventional biochemical tests according to Schaad et al. [30] protocols.

To check the non-pathogenicity of the isolates tested, $10 \mu \mathrm{l}$ of bacterial suspension $\left(\sim 10^{8}\right.$ cells $\left./ \mathrm{mL}\right)$ was inoculated to tobacco leaves using a syringe. Uninoculated control leaves were treated with SDW only (negative control). Tobacco plants (inoculated and uninoculated) were incubated at room temperature for $24 \mathrm{~h}$. Isolates inciting the development of chlorotic and/or necrotic zone on leaf areas were considered as pathogenic and thus, excluded from their eventual screening as BCAs [31].

\section{Identification of endophytic bacterial isolates by $16 \mathrm{~S}$ rDNA sequencing gene}

Molecular identification of the bacterial isolates was performed after extraction of the genomic DNA using the method described byvan Soolingen et al. [32] for Gram + bacteria. The $16 \mathrm{SrDNA}$ was amplified with the universal eubacterial primers 27f (5'-AGAGTTTGATC(A/C)TGGCTCAG-3') and 1492r (5'-TACGG(C/T)TACCTTGTTACGACTT-3') [4]. Amplifications were carried out in Thermal Cycler (CS Cleaver, Scientific Ltd., TC 32/80). The cycling conditions were as follows: one denaturing cycle at $94^{\circ} \mathrm{C}$ for $4 \mathrm{~min}$, followed by 40 denaturing cycles at $94^{\circ} \mathrm{C}$ for $30 \mathrm{~s}$, annealing at $45^{\circ} \mathrm{C}$ for $30 \mathrm{~s}$, and polymerization at $72^{\circ} \mathrm{C}$ for $45 \mathrm{~s}$. The amplification was terminated with an extension cycle at $72^{\circ} \mathrm{C}$ for $7 \mathrm{~min}$. The homology of the $16 \mathrm{~S} \mathrm{rDNA}$ sequence of a given isolate was performed using BLAST program from Genbank database (http: www.ncbi.nlm.gov/BLAST/). The six culturable endophytic bacteria (namely S42, SV39, SV41, SV44, SV65, and SV104) sequences were submitted to GenBank and were assigned the following accession numbers KP993206 KR818070, KR818071, KR818072, KR818073 and KR818089, respectively.

\section{In vitro antifungal activity test of endophytic Bacillus spp. isolates}

Dual culture method: The antagonistic potential of Bacillus spp. isolates against FOL was evaluated using the dual culture method on PDA. This method consists to streak bacterial isolates across the center of the Petri plate $(9 \mathrm{~cm}$ in diameter) and perpendicularly to the

\begin{tabular}{|c|c|c|c|c|}
\hline Isolate & Plant & $\begin{array}{c}\text { Source of bacterial } \\
\text { isolation }\end{array}$ & Locality & GPS locality \\
\hline S42 & $\begin{array}{l}\text { Nicotiana } \\
\text { glauca }\end{array}$ & Stems & Bekalta & $\begin{array}{l}\text { N35 } 37^{\circ} 14.327^{\prime \prime} ; \\
\text { E10 } 59^{\prime} 41.393^{\prime \prime}\end{array}$ \\
\hline SV39 & Datura metel & $\begin{array}{c}\text { Internal tissues of } \\
\text { stems }\end{array}$ & Chott-Mariem & $\begin{array}{l}\text { N35 } 55^{\circ} 66^{\prime 2} 2.451^{\prime \prime} ; \\
\text { E10 } 33^{\prime} 32.028^{\prime \prime}\end{array}$ \\
\hline SV41 & D. metel & $\begin{array}{c}\text { Internal tissues of } \\
\text { stems }\end{array}$ & Chott-Mariem & $\begin{array}{l}\text { N35 } 55^{\circ} 6^{\prime 2} 20.451^{\prime \prime} ; \\
\text { E10 } 33^{\prime} 32.028^{\prime \prime}\end{array}$ \\
\hline SV44 & D. metel & $\begin{array}{c}\text { Internal tissues of } \\
\text { stems }\end{array}$ & Chott-Mariem & $\begin{array}{l}\text { N35 } 55^{\circ} 66^{\prime 2} 20.451^{\prime \prime} ; \\
\text { E10 } 33^{\prime} 32.028^{\prime \prime}\end{array}$ \\
\hline SV65 & $\begin{array}{l}\text { Solanum } \\
\text { nigrum }\end{array}$ & $\begin{array}{c}\text { Internal tissues of } \\
\text { stems }\end{array}$ & Chott-Mariem & $\begin{array}{l}\text { N35 } 55^{\circ} 620.451 " ; \\
\text { E10 } 33^{\prime} 32.028^{\prime \prime}\end{array}$ \\
\hline SV104 & $\begin{array}{c}\text { S. } \\
\text { elaeagnifolium }\end{array}$ & $\begin{array}{c}\text { Internal tissues of } \\
\text { stems }\end{array}$ & M'saken & $\begin{array}{l}\mathrm{N} 35^{\circ} 43^{\prime} 32.073^{\prime \prime} ; \\
\mathrm{E} 10^{\circ} 34^{\prime} 48.90^{\prime \prime}\end{array}$ \\
\hline
\end{tabular}

Table 1: Endophytic bacterial isolates from wild Solanaceae plants and their isolation sources. 
Citation: Aydi Ben Abdallah R, Jabnoun-Khiareddine H, Mokni-Tlili S, Nefzi A, Medimagh-Saidana S, et al. (2015) Endophytic Bacillus spp. from Wild Solanaceae and Their Antifungal Potential against Fusarium oxysporum f. sp. Iycopersici Elucidated Using Whole Cells, Filtrate Cultures and Organic Extracts. J Plant Pathol Microbiol 6: 324. doi:10.4172/2157-7471.1000324

first streak. Four agar-plugs (6 $\mathrm{mm}$ in diameter), removed from the growing edge of a 7 day-old culture of FOL, were placed at each side of the tested bacterial isolate [33]. The control plates were streaked with SDW only. Each individual treatment was repeated four times. After 4 days of incubation at $25^{\circ} \mathrm{C}$, the colony diameter of the pathogen was measured. The mycelial growth inhibition rate of the pathogen (IR) was calculated using the formula of Dennis and Webster [34] as follows: IR $\mathrm{C}=[(\mathrm{C} 2-\mathrm{C} 1) / \mathrm{C} 2] \times 100$ where $\mathrm{C} 2$ : Mean diameter (two perpendicular measurements) of the control colony and $\mathrm{C} 1$ : Mean pathogen colony diameter in the presence of the antagonist.

Sealed plate method: This method of confrontation permits the detection of volatile metabolites produced by the bacterial isolate tested against FOL. Bacillus spp. were streaked onto NA in the bottom of Petri dish plate. An agar plug ( $6 \mathrm{~mm}$ in diameter), containing mycelium taken from 7-day-old pathogen culture, was placed in the center of a second Petri dish plate containing PDA amended with streptomycin sulfate $(300 \mathrm{mg} / \mathrm{L})(\mathrm{w} / \mathrm{v})$. The plate containing the pathogen mycelial plug was inverted over the bacterial plate and these two dishes were sealed with Parafilm in order to avoid evaporation of volatile compounds. In the control culture, the Petri dish below contained only NA without streaking bacteria [35]. The plates were incubated at $25^{\circ} \mathrm{C}$ for 7 days. Each individual treatment was repeated thrice. The mycelial growth inhibition rate of the pathogen was calculated as previously described.

\section{In vitro antifungal activity test of cell-free culture filtrates of endophytic Bacillus spp. isolates}

To determine the relationship between growth and production of antifungal metabolites, each Bacillus spp. isolate was cultured in LuriaBertani broth (LB) medium at $28 \pm 2^{\circ} \mathrm{C}$ for $1,2,3,4$ and 7 days and under continuous shaking at $150 \mathrm{rpm}$. Culture samples of $2 \mathrm{ml}$ each were taken at various time points and examined for their antifungal activity. Liquid cultures obtained were centrifuged for $10 \mathrm{~min}$ at 10,000 $\mathrm{rpm}$. The centrifugation was repeated three times. Supernatant fluids were sterilized by filtration through a $0.22 \mu \mathrm{m}$ pore size filter. The control was the LB filtrate. The filtrates were added at the concentration of $10 \%(\mathrm{v} / \mathrm{v})$ aseptically to Petri dishes containing PDA amended with streptomycin sulfate $(300 \mathrm{mg} / \mathrm{L})(\mathrm{w} / \mathrm{v})$. After solidification of the mixture, three agar plugs of the pathogen $(6 \mathrm{~mm}$ in diameter) were plated equidistantly in each Petri plate. Fungal cultures were incubated at $25^{\circ} \mathrm{C}$ for 4 days [36]. The colony diameter of the pathogen (treated and untreated control) was measured and the mycelial growth inhibition rate of the pathogen was calculated as described above.

\section{In vitro antifungal activity test of organic extracts from endophytic Bacillus spp. isolates}

To extract the antifungal metabolites produced by Bacillus spp., two types of extraction were carried out: one with chloroform [37] and a second with n-butanol [38]. Sixty milliliters $(60 \mathrm{~mL})$ of cellfree culture of each isolate, prepared as described above, were placed in a separating funnel. Then, $60 \mathrm{~mL}$ of the solvent (chloroform or n-butanol) were added carefully. The funnel was reversed several times by degassing from time to time. The mixture was allowed to settle for few minutes with the cap open. The organic phase (the lower phase for extraction with chloroform and the upper one with n-butanol) were collected. The aqueous phase was replaced in the funnel and the extraction was repeated two other times. The solvent was evaporated in a rotary evaporator at $35^{\circ} \mathrm{C}$ for chloroform and $75^{\circ} \mathrm{C}$ for n-butanol with a slight rotation at $150 \mathrm{rpm}$.

The obtained organic extracts were assessed for their biological activity against FOL. Each extract was suspended in ethanol (1:1) (mg/ $\mathrm{mL})(\mathrm{w} / \mathrm{v})$ and added to Petri dishes containing $10 \mathrm{ml}$ of PDA amended with streptomycin sulfate $(300 \mathrm{mg} / \mathrm{L})(\mathrm{w} / \mathrm{v})$ at two concentrations 2.5 and $5 \%(\mathrm{v} / \mathrm{v})$. The control cultures were treated with ethanol only used at 2.5 and $5 \%(\mathrm{v} / \mathrm{v})$. Antifungal activity of the metabolites produced by each isolate was compared to two commercial products i.e. Bavistin $^{\circledR}$ (50\%, chemical fungicide) and Bactospeine ${ }^{\circledR}$ (16000 UI/mg, biopesticide). Ethanol was used as negative control. After solidification of the mixture, a plug ( $6 \mathrm{~mm}$ in diameter) of FOL, obtained from PDA plate grown at $25^{\circ} \mathrm{C}$ for 7 days, was placed at the center of each plate. Fungal cultures were incubated for 7 days at $25^{\circ} \mathrm{C}$. The colony diameter of the treated and control pathogen were measured and the mycelial growth inhibition rate of the pathogen was calculated as described above.

\section{Statistical analysis}

Data were subjected to a one-way analysis of variance using Statistical Package for the Social Sciences (SPSS) software for Windows version 16.0. For all the in vitro bioessays, each treatment was repeated three or four times. Data of the antifungal activity of whole cells and cell-free cultures were analyzed according to a completely randomized design. The in vitro essay of organic extracts was analyzed according to a completely randomized factorial model with two factors (treatments and concentrations). Means were separated using Student-NewmanKeuls test at $\mathrm{P} \leq 0.05$.

\section{Results}

\section{Characterization and hypersensivity test of endophytic bacterial isolates}

All bacterial isolates were found to be Gram positive strains. The colony morphology of the six isolates showed an irregular form, rough surface and cream color on NA. These isolates were opaque. The isolate S42 showed flat elevation. SV39, SV41, SV44, SV65 and SV104 showed a humped elevation. A macroscopic variability was noted between the six isolates in terms of margin which was undulate (S42 and SV41), curly (SV39 and SV44), lobed (SV65) or irregular (SV104). Microscopically, the six isolates were rod-shaped and motile bacteria. They were able to produce catalase and indole by tryptophanase. SV39, SV41, SV44, SV65 and SV 104 used mannitol as a carbon source. S42, SV41, SV44 and SV104 used also the simmons citrate as a carbon source. Except SV39, all isolates were able to synthesize the nitrate reductase. Only the S42 was able to produce the lecithinase. The six isolates were oxidative strains. They cannot ferment glucose through the mixed acid (MR) but by using the glycol butylene path (PV+). They cannot produce hydrogen sulfide, lysine decarboxylase and pyocyanin on King A medium. Only SV39 can produce urease. SV41 and SV44 can produce the tryptophane desaminase (Table 2).

The hypersensivity test onto tobacco plants revealed, after 24 $\mathrm{h}$ of incubation, that all the inoculated leaves remained healthy. No hypersensitive reaction (HR) (chlorotic or necrotic zone) was detected on the leaf areas as compared to the inoculated control leaves. Thus, all the isolates tested were non pathogenic and were selected for further molecular identification and screening of their antifungal activity against FOL.

\section{Molecular identification of the bacterial isolates}

Blast analysis of sequenced 16S rDNA gene homology revealed that the six endophytic isolates tested belonged to the genus of Bacillus with $100 \%$ of similarity to B. cereus with strain S42 (KP993206) and 
Citation: Aydi Ben Abdallah R, Jabnoun-Khiareddine H, Mokni-Tlili S, Nefzi A, Medimagh-Saidana S, et al. (2015) Endophytic Bacillus spp. from Wild Solanaceae and Their Antifungal Potential against Fusarium oxysporum f. sp. lycopersici Elucidated Using Whole Cells, Filtrate Cultures and Organic Extracts. J Plant Pathol Microbiol 6: 324. doi:10.4172/2157-7471.1000324

\begin{tabular}{|c|c|c|c|c|c|c|}
\hline Biochemical tests & \multicolumn{7}{|c|}{ Bacterial isolates } \\
\hline & S42 & SV39 & SV41 & SV44 & SV65 & SV104 \\
\hline Catalase & + & + & + & + & + & + \\
\hline Red of Methyl & - & - & - & - & - & - \\
\hline Vosges-Proskauer & + & + & + & + & + & + \\
\hline Mannitol & - & + & + & + & + & + \\
\hline Lecithinase & + & - & - & - & - & - \\
\hline Indole & + & + & + & + & + & + \\
\hline Simmons Citrate & + & - & + & + & - & + \\
\hline Urease & - & + & - & - & - & - \\
\hline $\begin{array}{c}\text { Tryptophane } \\
\text { desaminase }\end{array}$ & - & - & + & + & - & - \\
\hline Nitrate reducatase & + & - & + & + & + & + \\
\hline Glucose & + & + & + & + & + & - \\
\hline Lactose & - & - & - & - & - & + \\
\hline Gaz & + & + & + & + & + & - \\
\hline Hydrogen sulfide & - & - & - & - & - & - \\
\hline King A & - & - & - & - & - & - \\
\hline
\end{tabular}

Table 2: Biochemical characterization of the six bacterial isolates from wild Solanaceae stems. +: Positive test, -: Negative test. S42: Bacterial isolate from Nicotiana glauca stems; SV39, SV41 and SV44: Bacterial isolates from internal tissues of stems of Datura metel; SV65: Bacterial isolate from internal tissues of stems of Solanum nigrum; SV104: Bacterial isolate from internal tissues of stems of S.elaeagnifolium.

\begin{tabular}{|c|c|c|c|}
\hline Isolate & $\begin{array}{c}\text { Accession } \\
\text { number }\end{array}$ & Most related species & $\begin{array}{c}\text { Sequence homology } \\
\text { (\%) }\end{array}$ \\
\hline S42 & KP993206 & 265XY1, Bacillus cereus & 100 \\
\hline SV39 & KR818070 & BD18-B03, Bacillus tequilensis & 99 \\
\hline SV41 & KR818071 & 264ZY7, Bacillus subtilis & 99 \\
\hline SV44 & KR818072 & LK6, Bacillus methylotrophicus & 99 \\
\hline SV65 & KR818073 & $\begin{array}{c}\text { Hs8-12, Bacillus } \\
\text { amyloliquefaciens subsp. } \\
\text { plantarum }\end{array}$ & 99 \\
\hline SV104 & KR818089 & ifo 15718, Bacillus mojavensis & 99 \\
\hline
\end{tabular}

Table 3: Identification of endophytic bacteria isolates by $16 \mathrm{~S}$ rDNA sequencing genes.

99\% of similarity to B. tequilensis, B. subtilis, B. methylotrophicus, B. amyloliquefaciens subsp. plantarum and B. mojavensis with isolates SV39 (KR818070), SV41 (KR818071), SV44 (KR818072), SV65 (KR818073) and SV104 (KR818089), respectively (Table 3).

\section{Assessment of the in vitro antifungal activity of Bacillus spp. using whole cell suspension}

Tested using the dual culture method in PDA, all Bacillus spp. isolates showed a significant inhibitory effect (at $\mathrm{P} \leq 0.05)$ against FOL, after 4 days of incubation at $25^{\circ} \mathrm{C}$, compared to the untreated control. The reduction of FOL mycelium growth varied from 36.7 to $46.5 \%$. The isolate SV65 of B. amyloliquefaciens subsp. plantarum inhibited FOL growth by $46.5 \%$ followed by $44.4,44.1,42.4,38.7$, and $36.7 \%$ recorded using the isolates SV41 of B. subtilis, S42 of B. cereus, SV44 of B. methylotrophicus (Figure 1a), SV104 of B. mojavensis, and SV39 of B. tequilensis, respectively (Table 4). This antifungal potential against of FOL may be attributed to diffusible metabolites produced by Bacillus spp.

Results shown in Table 4 revealed also that Bacillus spp. tested, using the sealed plate method, also exhibited a significant inhibitory effect (at $\mathrm{P} \leq 0.05$ ) against FOL. Pathogen growth reduction varied significantly from 18.2 to $21.6 \%$ as compared to the untreated control. The antifungal effect induced by SV44 of B. methylotrophicus (Figure 1b) was expressed by $21.6 \%$ decrease in pathogen growth, as compared to the untreated control, followed by SV65 of B. amyloliquefaciens subsp. plantarum (20.3\%), SV104 of B. mojavensis (20.8\%), S42 of B. cereus (19.2\%), SV39 of B. tequilensis and SV41 of B. subtilis (18.2\%). This revealed the ability of endophytic Bacillus spp. to inhibit pathogen at distance through antifungal volatile compounds.

\section{Assessment of the in vitro antifungal activity of Bacillus spp. using cell-free cultures}

Analysis of variance revealed a significant (at $\mathrm{P} \leq 0.05$ ) variation in the diameter of FOL colonies treated with the cell-free culture of Bacillus spp. tested at $10 \%(\mathrm{v} / \mathrm{v})$ issued from 2-, 3-, 4-, and 7- dayold culture in $\mathrm{LB}$ medium at $28 \pm 2{ }^{\circ} \mathrm{C}$. However, all cell-free culture

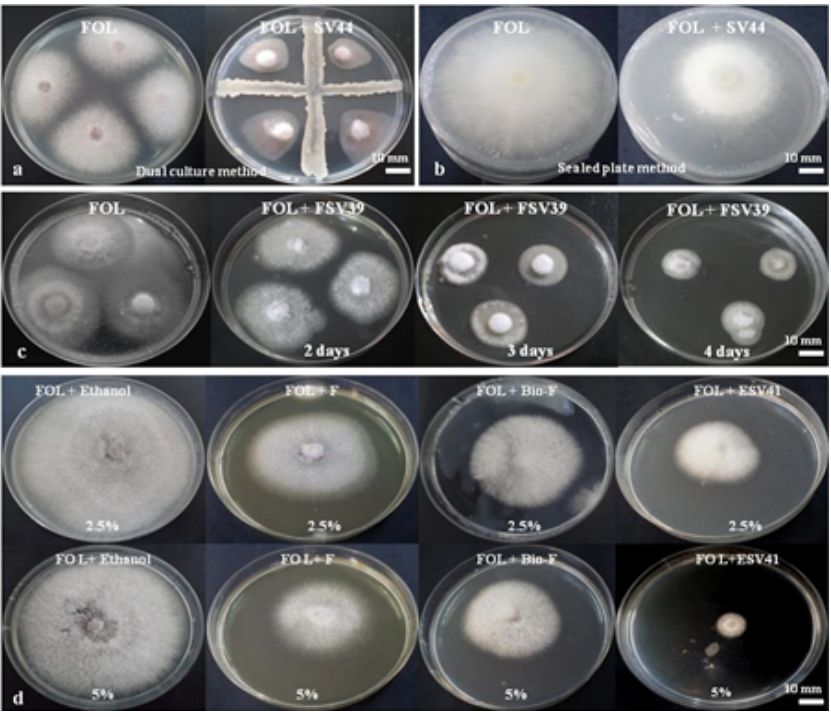

Figure 1: Antifungal activity of endophytic Bacillus spp. against Fusarium oxysporum f. sp. lycopersici attributed to diffusible (a) and volatile (b) metabolites, cell-free filtrates from 2 to 4-day-old bacterial cultures (c) and organic extracts tested at two concentrations (d) as compared to controls. SV44: Whole cell suspension of Bacillus methylotrophicus str. SV44; FSV39: Cell-free culture from Bacillus tequilensis str. SV39; Ethanol: Negative control; F: Positive control (Bavistin $®$, chemical fungicide); Bio-F: Positive control (Bactospeine $\AA$, Bio-pesticide); ESV41: Chloroform extract from $B$. subtilis str. SV41.

\section{Bacterial treatments}

Colony diameter $(\mathrm{cm})$ and growth inhibition of FOL (\%) Diffusible Volatile metabolites metabolites

Untreated control

Bacillus cereus str. S42 (KP993206)

Bacillus tequilensis str. SV39 (KR818070

$3.71 \mathrm{a} \mathrm{(0)} \quad 6.42 \mathrm{a}(0)$

Bacillus subtilis str. SV41 (KR818071)

Bacillus methylotrophicus str. SV44

(KR818072)

$2.07 \mathrm{~b}(44.1) \quad 5.18 \mathrm{~b}(19.2)$

$2.35 \mathrm{~b}(36.7) \quad 5.25 \mathrm{~b}(18.2)$

$2.06 \mathrm{~b}(44.4) \quad 5.25 \mathrm{~b}(18.2)$

Bacillus amyloliquefaciens subsp. plantarum str. SV65 (KR818073)

Bacillus mojavensis str. SV104 (KR818089)

$2.14 \mathrm{~b}(42.4) \quad 5.03 \mathrm{~b}(21.6)$

$1.99 \mathrm{~b}(46.5) \quad 5.12 \mathrm{~b}(20.3)$

$2.27 \mathrm{~b}(38.3) \quad 5.08 \mathrm{~b}(20.8)$

Table 4: Mycelial growth inhibition of Fusarium oxysporum f. sp. lycopersic by diffusible and/or volatile metabolites produced by endophytic Bacillus spp. isolates, as compared to the controls, noted after 4 and 7 days of incubation at $25^{\circ} \mathrm{C}$, respectively. For each column, values followed by the same letter are not significantly different according to Student Newman Keuls test at $P \leq 0.05$. Numbers in parenthesis indicate the percentage (in \%) of the mycelial growth inhibition of Fusarium oxysporum f. sp. lycopersici as compared to the untreated control. 
Citation: Aydi Ben Abdallah R, Jabnoun-Khiareddine H, Mokni-Tlili S, Nefzi A, Medimagh-Saidana S, et al. (2015) Endophytic Bacillus spp. from Wild Solanaceae and Their Antifungal Potential against Fusarium oxysporum f. sp. Iycopersici Elucidated Using Whole Cells, Filtrate Cultures and Organic Extracts. J Plant Pathol Microbiol 6: 324. doi:10.4172/2157-7471.1000324

\begin{tabular}{|c|c|c|c|c|c|}
\hline \multirow{2}{*}{$\begin{array}{c}\text { Treatment } \\
\text { tested }\end{array}$} & \multicolumn{5}{|c|}{ Duration of bacterial culture incubation (days) } \\
\hline & 1 & 2 & 3 & 4 & 7 \\
\hline Control & $3.42 \mathrm{a}$ & $4.03 \mathrm{a}$ & $3.62 \mathrm{a}$ & $3.7 \mathrm{a}$ & $3.87 \mathrm{a}$ \\
\hline FS42 & 3.18 a (2) & 3.58 a (11.2) & $2.8 \mathrm{~b}(22.6)$ & $2.55 \mathrm{~b}(31.1)$ & $3.28 \mathrm{ab}(15.2)$ \\
\hline FSV39 & 3.35 a (2) & 3.52 a (12.6) & $2.22 \mathrm{~b}(38.7)$ & 1.93 c (47.8) & $2.38 \mathrm{~b}(38.5)$ \\
\hline FSV41 & 3.13 a (8.5) & 3.38 a (16.1) & $2.37 \mathrm{~b}(34.5)$ & 2.03 c (45.1) & $2.48 \mathrm{~b}(35.9)$ \\
\hline FSV44 & 3.18 a (7) & 3.47 a (13.9) & $2.53 \mathrm{~b}(30.1)$ & 1.88 c (49.2) & $3.03 \mathrm{~b}(21.7)$ \\
\hline FSV65 & 3.18 a (7) & 2.5 b (37.9) & $1.97 \mathrm{~b}(45.6)$ & 1.50 c (59.5) & $2.33 \mathrm{~b}(39.8)$ \\
\hline FSV104 & 3.08 a (9.9) & 3.48 a (13.6) & $2.02 \mathrm{~b}(44.2)$ & 2.02 c (45.4) & $2.47 \mathrm{~b}(36.2)$ \\
\hline
\end{tabular}

Table 5: Effect of cell-free cultures from endophytic Bacillus spp., prepared a different durations of incubation, against Fusarium oxysporum f. sp. lycopersici mycelial growth noted after 4 days of incubation at $25^{\circ} \mathrm{C}$ as compared to the untreated controls. FS42, FSV39, FSV41, FSV44, FSV65 and FSV104: Cellfree culture filtrates of isolates S42 of $B$. cereus, SV39 of $B$. tequilensis, SV41 of $B$. subtilis, SV44 of B. methylotrophicus, SV65 of B. amyloliquefaciens subsp. plantarum and SV104 of B. mojavensis, respectively. Control: Luria-Bertani broth medium filtrate. For each incubation duration, values followed by the same letter are not significantly different according to Student Newman Keuls test at $P \leq 0.05$. Numbers in parenthesis indicate the percentage (in \%) of the mycelial growth inhibition of Fusarium oxysporum f. sp. lycopersici as compared to the untreated control.

filtrates issued from 1 day-old cultures did not decrease significantly (2 to 9.9\%) pathogen growth. Cell-free cultures were found to be mostly effective when extracted from 4 days-old cultures where growth inhibition achieved varied from 31.1 to $59.5 \%$ as compared to 22.6 $45.6 \%, 15.2-39.8 \%$, and $11.2-37.9 \%$ recorded at 3,7 , and 2 days of incubation, respectively. For example, the cell-free culture of SV39 of B. tequilensis, issued from 4 days-old cultures, inhibited the pathogen growth by $47.8 \%$ whereas $38.7,38.5,12.6$, and $2 \%$ were recorded using filtrates extracted after 3, 7, 2 and 1 day (s) of incubation, respectively (Table 5 and Figure 1c). The highest reduction (37.9, 45.6, 59.5, and $39.8 \%$ ) of FOL mycelial growth was recorded using the filtrate of SV65 of B. amyloliquefaciens subsp. plantarum from 2-, 3-, 4-, and 7-daysold of cultures respectively, as compared to the controls (Table 5). Thus, the optimum incubation duration of Bacillus spp. cultures for the production of the most effective antifungal metabolites against FOL was found to be of about 3 to 4 days.

Assessment of the in vitro antifungal activity of organic extracts from endophytic Bacillus spp.

ANOVA analysis revealed a significant $($ at $\mathrm{P} \leq 0.05)$ variation in the average diameter of FOL colonies depending on the organic extracts (chloroform and n-butanol extracts) tested and the concentrations used, and the existence of a significant interaction between both factors. Results shown in Figure 2 indicated that all organic extracts, used 1 $\mathrm{mg} / \mathrm{mL}(\mathrm{w} / \mathrm{v}$ ), had inhibited FOL growth by 37 to $90 \%$ as compared to the ethanol controls. The decrease in FOL growth was higher with these organic extracts as compared to Bavistin ${ }^{\circledR}$ (31.3-39.5\%) and Bactospeine $^{\circledR}$ (40.9-43.2\%) whatever the concentration used (Figures 1d and 2).

All organic extracts of Bacillus spp. were found to be more active at the concentration of $5 \%$ than at $2.5 \%(\mathrm{v} / \mathrm{v})$, except the chloroform extract of $S 42$ of $B$. cereus. In fact, all the organic extracts from the antagonistic agents used at $5 \%(\mathrm{v} / \mathrm{v})$ had significantly reduced, by 57.4 to $90 \%$, FOL growth compared to 37 to $72.4 \%$ recorded using $2.5 \%(\mathrm{v} / \mathrm{v})$ concentration. Chloroform extracts of isolates SV65 of $B$. amyloliquefaciens subsp. plantarum, SV41 of B. subtilis (Figure 1d), and SV44 of B. methylotrophicus decreased pathogen growth by 73.02, 72.79 , and $57.44 \%$, respectively, when applied at $5 \%(\mathrm{v} / \mathrm{v})$, compared to $43.4,54.8$ and $49.9 \%$ recorded at $2.5 \%(\mathrm{v} / \mathrm{v})$ (Figure 2). In addition, n-butanol extracts of isolates SV104 of B. mojavensis, SV44 of B. methylotrophicus, and SV41 of B. subtilis, applied at 5\%, inhibited the pathogen growth by $88.4,88.6$ and $83.2 \%$ compared to $37,47.6$ and $48.7 \%$ noted with the concentration $2.5 \%$ (Figure 2).

The highest inhibition (90\%) was achieved using the n-butanol extract from SV65 of B. amyloliquefaciens subsp. plantarum followed by $88.6,88.3$ and $83.2 \%$ obtained with n-butanol extracts from SV44 of B. methylotrophicus, SV104 of B. mojavensis, and SV41 of B. subtilis, respectively used at $5 \%(\mathrm{v} / \mathrm{v})$ as compared to the ethanol control (Figure 2). Tested at $2.5 \%(\mathrm{v} / \mathrm{v})$, chloroform extracts from SV39 of B. tequilensis and $\mathrm{S} 42$ of $B$. cereus exhibited the highest antifungal potential towards FOL (72.4 and $71.7 \%$, respectively) (Figure 2).

\section{Discussion}

Bacillus spp. are known for their diverse range of secondary metabolites including antibiotics, lytic enzymes and volatile organic compounds with antifungal, antibacterial, nematicidal, insecticidal and immunosuppressant activities [39-42]. While a wide range of biologically active compounds have been isolated from endophytic

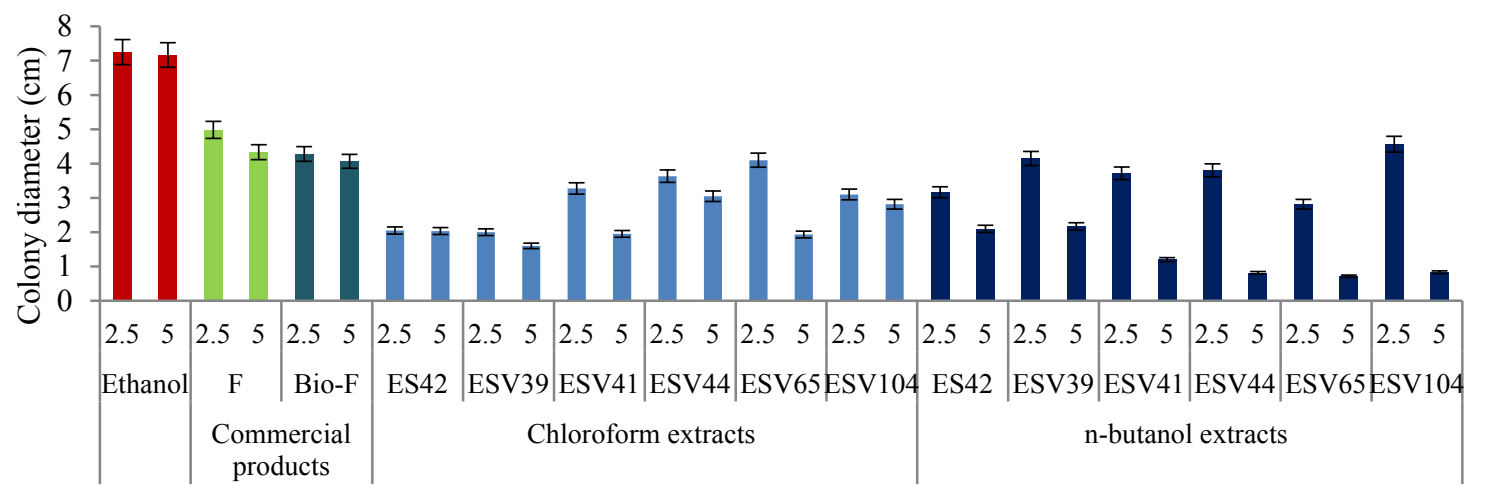

Treatments tested at two concentrations ( $\% \mathrm{v} / \mathrm{v})$

Figure 2: Effect of chloroform and n-butanol extracts from endophytic Bacillus spp. tested at two concentrations against Fusarium oxysporum f. sp. Iycopersici noted after 7 days of incubation at $25^{\circ} \mathrm{C}$ as compared to the control and to the commercial products used. ES42, ESV39, ESV41, ESV44, ESV65 and ESV104: Organic extracts from isolates S42 of $B$. cereus, SV39 of B. tequilensis, SV41 of $B$. subtilis, SV44 of $B$. methylotrophicus, SV65 of $B$. amyloliquefaciens subsp. plantarum and SV104 of B. mojavensis, respectively; Control: Ethanol control. F: Bavistin ${ }^{\circledR}$ (Chemical fungicide); Bio-F: Bactospeine ${ }^{\circledR}$ (Bio-pesticide). LSD (Treatments tested $\times$ Concentrations used): $0.44 \mathrm{~cm}$ at $P \leq 0.05$. 
Citation: Aydi Ben Abdallah R, Jabnoun-Khiareddine H, Mokni-Tlili S, Nefzi A, Medimagh-Saidana S, et al. (2015) Endophytic Bacillus spp. from Wild Solanaceae and Their Antifungal Potential against Fusarium oxysporum f. sp. Iycopersici Elucidated Using Whole Cells, Filtrate Cultures and Organic Extracts. J Plant Pathol Microbiol 6: 324. doi:10.4172/2157-7471.1000324

organisms, they still remain a relatively untapped source of novel natural products [43]. In this study, six culturable Bacillus spp. isolates (B. cereus str. S42, B. tequilensis str. SV39, B. subtilis str. SV41, B. methylotrophicus str. SV44, B. amylolequifaciens subsp. plantarum str. SV65 and B. mojavensis str. SV104), isolated from healthy stems of wild Solanaceae species (N. glauca, D. metel, S. nigrum and S. elaeagnifolium), were evaluated for their antifungal potential towards FOL and they have been explored as potential sources of bioactive metabolites.

Tested using the dual culture method, Bacillus spp. exhibited a strong antifungal activity against FOL that may be attributed to their diffusible active metabolites. Previous studies have shown that endophytic Bacillus spp., isolated from Salvia miltiorrhiza [24] and/or Pinus taeda L. [44] may be useful as BCAs and potential sources of bioactive molecules. Bacillus species were also reported to produce nonvolatile antifungal metabolites $[6,45]$ and/or volatile compounds [41]. In fact, tested using the sealed plate method, all Bacillus spp. isolates tested in the current study had significantly reduced FOL growth compared to the untreated control. This method of confrontation revealed the presence of antifungal volatile metabolites active against FOL. The diffusible metabolites from Bacillus spp., tested in the present study, caused greater growth inhibition of FOL (38.7 to $46.5 \%)$ than the volatile compounds (18.2 to $21.6 \%$ ). However, Chaurasia et al. [35] found that the inhibitory effect attributed to volatiles was greater than that induced by diffusible compounds where B. subtilis was used as an antagonistic agent against $F$. oxysporum, Alternaria alternata, Cladosporium oxysporum, Paecilomyces lilacinus, Paecilomyces variotii, and Pythium afertile.

In order to optimize the production of antifungal metabolites, cellfree filtrates of the six Bacillus spp. isolates were extracted from cultures grown at different times of incubation. Results showed a significant inhibition of the pathogen using filtrates issued from 2-, 3-, 4-, and 7-day-old cultures with a maximum (from 31.1 to $59.5 \%$ ) recorded after 4 days of incubation compared to the untreated controls. Romero et al. [38] found that the antifungal activity of the cell-free cultures of B. subtilis was detected at the transition phase between exponential and stationary phase of growth. This activity increased progressively during the later and reached its highest levels after 4 to 5 days of culture when bacterial populations were composed mainly by spores. Our findings clearly demonstrated the possibility of using $B$. cereus str. S42, $B$. tequilensis str. SV39, B. subtilis str. SV41, B. methylotrophicus str. SV44, B. amyloliquefaciens subsp. plantarum str. SV65 and B. mojavensis str. SV104 as sources of biologically active natural products with an optimum of metabolites production recorded at 4 days of incubation. Other studies also reported secondary metabolites from endophytic Bacillus spp. with inhibitory effects against Fusarium spp. and other plant pathogens [16,44].

The secondary metabolites produced by Bacillus species exhibited diverse chemical structures and biological activities [47]. All organic extracts tested had significantly reduced FOL growth by 37 to $90 \%$, compared to the ethanol controls, and this depending upon the concentrations used. Biologically active metabolites extracted with ethyl acetate, diethyl ether, chloroform, n-hexane, acetone and n-butanol from endophytic Bacillus species also inhibited the mycelial growth of several pathogenic fungi and/or bacteria [42,16,17].

The two types of organic extracts from Bacillus spp. isolates tested were found to be more effective at the concentration of $5 \%$ than at $2.5 \%$ (v/v). The highest antifungal potential toward FOL growth (90\%) was achieved using the n-butanol extract from B. amylolequifaciens subsp. plantarum str. SV65 used at $1 \mathrm{mg} / \mathrm{mL}(\mathrm{w} / \mathrm{v})$. In the same sense, the n-butanol extract from endophytic B. subtilis str. ZZ120 $(1 \mathrm{mg} / \mathrm{mL} \mathrm{w} / \mathrm{v})$ led to $61.4 \%$ decrease in $F$. graminearum growth [16]. Tested at $2.5 \%$ (v/v), chloroform extracts from B. tequilensis str. SV39 and B. cereus str. S42 reduced pathogen growth by 72.4 and $71.3 \%$, respectively as compared to the ethanol control. Bhoonobtong et al. [37] also demonstrated the antifungal potential of chloroform extracts from an endophtyic B. amylolequifaciens str. D25, isolated from medicinal plant, towards Staphylococccus aureus. However, chloroform extracts from four strains of B. subtilis (B. subtilis str. UMAF6614, B. subtilis str. UMAF6619, B. subtilis str. UMAF6639 and B. subtilis str. UMAF8561) were found to be ineffective towards the pathogen Botrytis cinerea [38]. Previous studies, using Bacillus spp. extracts showed that the major identified chemical substances belonged to the families of aldheydes, ketones, benzenes [47], dimethyl disulfide [48] and phthalic acids [27].

\section{Conclusion}

Plant-associated microorganisms, especially endophytic bacteria, represent largely untapped resources of natural products. Six nonpathogenic and culturable Bacillus spp. (B. cereus str. S42 (KP993206), B. tequilensis str. SV39 (KR818070), B. subtilis str. SV41 (KR818071), B. methylotrophicus str. SV44 (KR818072), B. amyloliquefaciens subsp. plantarum str. SV65 (KR818073) and B. mojavensis str. SV104 (KR818089)), isolated from stems of wild Solanaceae (N. glauca, D. metel, S. nigrum and S. elaeagnifolium), were found to be potential sources of non-volatile and/or volatile bioactive metabolites effective against FOL. Chloroform and n-butanol extracts from Bacillus spp. exhibited an interesting antifungal potential towards FOL higher than that induced by the two commercial products i.e. Bavistin $^{\circledR}\left(50 \%\right.$, chemical fungicide) and Bactospeine ${ }^{\circledR}$ (16000UI/mg, biopesticide). These endophytic bacterial isolates could be interesting for use as bio-fungicides against FOL.

Testing the antifungal activity of cell-free cultures of these Bacillus spp. isolates and their organic extracts in vivo may give additional information on their effects on Fusarium wilt suppression and tomato growth promotion. Chemical analyzes of the most effective organic extracts will identify the major compounds.

\section{Acknowledgements}

This work was funded by the Ministry of Higher Education and Scientific Research of Tunisia through the funding allocated to the research unit UR13AGR09Integrated Horticultural Production in the Tunisian Centre-East. We also thank all the team of sequencing in Faculty of Sciences, Campus Manar, Tunis, Tunisia.

\section{References}

1. Ignjatov M, Miloševic D, Nikolic Z, Gvozdanovic-Varga J, Jovicic D, et al. (2012) Fusarium oxysporum as causal agent of tomato wilt and fruit rot. Pestic Phytomed 27: 25-31.

2. McGovern RJ (2015) Management of tomato diseases caused by Fusarium oxysporum. Crop Prot 73: 78-92.

3. Minuto A, Spadaro D, Garibaldi A, Gullino ML (2006) Control of soilborne pathogens of tomato using a commercial formulation of Streptomyces griseoviridis and solarization. Crop Prot 25: 468-475

4. Moretti M, Gilardi G, Gullino ML, Garibaldi A (2008) Biological control potential of Achromobacter xylosoxydans for suppressing Fusarium wilt of tomato. Int $\mathrm{J}$ Bot 4: 369-375.

5. Amini J, Sidovich DF (2010) The effect of fungicides on Fusarium oxysporum f. sp. Iycopersici associated with Fusarium wilt of tomato. J Plant Prot Res 50: $172-178$.

6. Ongena M, Jacques $P$ (2008) Bacillus lipopeptides: versatile weapons for plant disease biocontrol. Trends Microbiol 16: 115-125.

7. Ge HL, Zhao HL, Guo JH (2004) Research and development situation of 
Citation: Aydi Ben Abdallah R, Jabnoun-Khiareddine H, Mokni-Tlili S, Nefzi A, Medimagh-Saidana S, et al. (2015) Endophytic Bacillus spp. from Wild Solanaceae and Their Antifungal Potential against Fusarium oxysporum f. sp. lycopersici Elucidated Using Whole Cells, Filtrate Cultures and Organic Extracts. J Plant Pathol Microbiol 6: 324. doi:10.4172/2157-7471.1000324

microbiological pesticide in plant soilborn diseases. J Anhui Agric Sci (in Chinese) 32: 153-155.

8. Di Pietro A, Madrid MP, Caracuel Z, Delgado-Jarana J, Roncero MI (2003) Fusarium oxysporum: exploring the molecular arsenal of a vascular wilt fungus. Mol Plant Pathol 4: 315-325.

9. Vethavalli S, Sudha SS (2012) In vitro and in silico studies on biocontro agent of bacterial strains against Fusarium oxysporum f. sp. lycopersici. Res Biotechnol 3: 22-31.

10. Reis A, Costa H, Boiteux LS, Lopes CA (2005) First report of Fusarium oxysporum f. sp. Iycopersici race 3 on tomato in Brazil. Fitopatol Bras 30: 426428

11. Vos CM, Yang Y, De Coninck B, Cammue BPA (2014) Fungal (-like) biocontro organisms in tomato disease control. Biol Control 74: 65-81.

12. Gond SK, Bergen MS, Torres MS, White JF Jr (2015) Endophytic Bacillus spp. produce antifungal lipopeptides and induce host defence gene expression in maize. Microbiol Res 172: 79-87.

13. Yang R, Fan X, Cai X, Hu F (2015) The inhibitory mechanisms by mixtures of two endophytic bacterial strains isolated from Ginkgo biloba against pepper Phytophthora Blight. Biol Control 85: 59-67.

14. Rajendran L, Samiyappan R (2008) Endophytic Bacillus species confer increased resistance in cotton against damping off disease caused by Rhizoctonia solani. Plant Pathol J 7: 1-12.

15. He RL, Wang GP, Liu XH, Zhang CL, Lin, FC (2009) Antagonistic bioactivity of an endophytic bacterium isolated from Epimedium brevicornu Maxim. Afr J Biotechnol 8: 191-195.

16. Li H, Wang X, Han M, Zhao Z, Wang M, et al. (2012) Endophytic Bacillus subtilis ZZ120 and its potential application in control of replant diseases. Afr $J$ Biotechnol 11: 231-242.

17. Paul NC, Ji SH, Deng JX, Yu SH (2013) Assemblages of endophytic bacteria in chili pepper (Capsicum annuum L.) and their antifungal activity agains phytopathogens in vitro. Plant Omics Journal 6: 441-448.

18. Sgroy V, Cassán F, Masciarelli O, Del Papa MF, Lagares A, et al. (2009) Isolation and characterization of endophytic plant growth-promoting (PGPB) or stress homeostasis-regulating (PSHB) bacteria associated to the halophyte Prosopis strombulifera. Appl Microbiol Biotechnol 85: 371-381.

19. Wang Y, Zeng Q, Zhang Z, Yan R, Zhu D (2010) Antagonistic bioactivity of an endophytic bacterium H-6. Afr J Biotechnol 9: 6140-6145.

20. Bibi F, Yasir M, Song GC, Lee SY, Chung YR (2012) Diversity and characterization of endophytic bacteria associated with tidal flat plants and their antagonistic effects on Oomycetous plant pathogens. Plant Pathol J 28: 20-31.

21. Izhaki I, Fridman S, Gerchman Y, Halpern M (2013) Variability of bacterial community composition on leaves between and within plant species. Curr Microbiol 66: 227-235.

22. Cao L, Qiu Z, You J, Tan H, Zhou S (2005) Isolation and characterization of endophytic streptomycete antagonists of Fusarium wilt pathogen from surfacesterilized banana roots. FEMS Microbiol Lett 247: 147-152.

23. He L, Zhou G, Lu L, Liu J (2009b) Isolation and identification of endophytic bacteria antagonistic to Camellia oleifera anthracnose. Afr J Microbiol Res 3 : 315-318.

24. Yan X, He L, Song G, Wang R. (2011) Antagonistic bioactivity of endophytic strains isolated from Salvia miltiorrhiza. Afr J Biotechnol 10: 15117-15122.

25. Sun L, Lu Z, Bie X, Lu F, Yang S (2006) Isolation and characterization of a co-producer of fengycins and surfactins, endophytic Bacillus amyloliquefaciens ES-2, from Scutellaria baicalensis Georgi. World J Microbiol Biotechnol 22: 1259-1266.

26. Pleban S, Chernin L, Chet I (1997) Chitinolytic activity of an endophytic strain of Bacillus cereus. Lett Appl Microbiol 25: 284-288.

27. Kumar GA, Antony AR, Kannan VR (2015) Exploration of endophytic microorganisms from selected medicinal plants and their control potential to multi drug resistant pathogens. J Med Plants Stud 3: 49-57.

28. McInroy JA, Kloepper JW (1995) Population dynamics of endophytic bacteria in field-grown sweet corn and cotton. Can J Microbiol 41: 895-901.
29. Patel HA, Patel RK, Khristi SK, Parikh K, Rajendran G (2012) Isolation and characterization of bacterial endophytes from Lycopersicon esculentum plant and their plant growth promoting characteristics. Nepal J Biotechnol 2: 37-52.

30. Schaad NW, Jones JB, Chun W (2001) Laboratory guide for identification of plant pathogenic bacteria. In: 3rd edition Paul, USA: American Phytopathological Society Press

31. Nawangsih AA, Damayanti I, Wiyono S, Kartika JG (2011) Selection and characterization of endophytic bacteria as biocontrol agents of tomato bacterial wilt disease. J Biosci 18: 66-70.

32. van Soolingen D, de Haas PE, Hermans PW, van Embden JD (1994) DNA fingerprinting of Mycobacterium tuberculosis. Methods Enzymol 235: 196-205.

33. Sadfi N, Chérif M, Fliss I, Boudabbous A, Antoun H (2001) Evaluation of bacterial isolates from salty soils and Bacillus thuringiensis strains for the biocontrol of Fusarium dry rot of potato tubers. J Plant Pathol 83: 101-118.

34. Dennis C, Webster J (1971) Antagonistic properties of species groups of Trichoderma I. Production of non-volatile antibiotics. Trans Br Mycol Soc 57 25-39.

35. Chaurasia B, Pandey A, Palni LM, Trivedi P, Kumar B, et al. (2005) Diffusible and volatile compounds produced by an antagonistic Bacillus subtilis strain cause structural deformations in pathogenic fungi in vitro. Microbiol Res 160 75-81.

36. Karkachi NE, Gharbi S, Kihal M, Henni JE (2010) Biological control of Fusaruim oxysporum f. sp. lycopersici isolated from Algerian tomato by Pseudomonas fluorescens, Bacillus cereus, Serratia marcescens and Trichoderma harzianum. Res J Agrn 4: 31-34.

37. Bhoonobtong A, Sawadsitang S, Sodngam S, Mongkolthanaruk W (2012) Characterization of endophytic bacteria, Bacillus amyloliquefaciens for antimicrobial agents. Production International Conference on Biological and Life Sciences 40: 6-11.

38. Romero D, de Vicente A, Rakotoaly RH, Dufour SE, Veening JW, et al. (2007) The iturin and fengycin families of lipopeptides are key factors in antagonism of Bacillus subtilis toward Podosphaera fusca. Mol Plant Microbe Interact 20 430-440.

39. Broderick NA, Raffa KF, Handelsman J (2006) Midgut bacteria required for Bacillus thuringiensis insecticidal activity. Proc Natl Acad Sci USA 103: 1519615199.

40. Pal KK, McSpadden Gardener B (2006) Biological control of plant pathogens The Plant Health Instructor 2: 1117-1142.

41. Leelasuphakul W, Hemmaneea P, Chuenchitt S (2008) Growth inhibitory properties of Bacillus subtilis strains and their metabolites against the green mold pathogen (Penicillium digitatum Sacc.) of citrus fruit. Postharvest Bio Technol 48: 113-121.

42. Harni R, Supramana, Supriadi (2014) Efficacy of endophytic bacteria in reducing plant parasitic nematode Pratylenchus brachyurus. Indones J Agric Sci 15: 29-34

43. Ryan RP, Germaine K, Franks A, Ryan DJ, Dowling DN (2008) Bacteria endophytes: recent developments and applications. FEMS Microbiol Lett 278 $1-9$

44. Soria S, Alonso R, Bettucci L (2012) Endophytic bacteria from Pinus taeda L. as biocontrol agents of Fusarium circinatum Nirenberg \& O'donnell. Chilean $\mathrm{J}$ Agric Res 72: 281-284

45. El-Hamshary OIM, Salem HH, Soliman NA (2008) Molecular screening of chitinase gene in Bacillus spp. J Appl Sci Res 4: 1118-1123.

46. Cho MK, Math K, Hong SY, Islam SMDA, Mandanna D, et al. (2009) Iturin produced by Bacillus pumilus HY1 from Korean soybean sauce (Kanjang) inhibits growth of aflatoxin producing fungi. Food Control 20: 402-406.

47. Yuan J, Raza W, Shen Q, Huang Q (2012) Antifungal activity of Bacillus amyloliquefaciens NJN-6 volatile compounds against Fusarium oxysporum f. sp. cubense. Appl Environ Microbiol 78: 5942-5944.

48. Huang CJ, Tsay JF, Chang SY, Yang HP, Wu WS, et al. (2012) Dimethy disulfide is an induced systemic resistance elicitor produced by Bacillus cereus C1L. Pest Manag Sci 68: 1306-1310. 